\title{
Legal Protection of Ikat-Pahikung Woven Fabric Motifs in East Sumba Regency
}

\author{
Rambu Susanti Mila Maramba1*, Rambu Hada Indah¹, Pajaru Lombu ${ }^{1}$ \\ ${ }^{1}$ Faculty of Business Law and Humanities, Universitas Wira Wacana Sumba Christian, Indonesia \\ *Correspondence: ramburasti@yahoo.com
}

\author{
ARTICLE HISTORY \\ Received: 09.11.2021 \\ Accepted: 21.12.2021 \\ Published: 27.12.2021

\section{ARTICLELICENCE} \\ Copyright (C) 2021 The \\ Author(s): This is an \\ open-access article \\ distributed under the \\ terms of the Creative \\ Commons Attribution \\ ShareAlike 4.0 \\ International (CC BY-SA \\ 4.0)
}

\begin{abstract}
Ikat weaving has been a source of employment, an important livelihood for the family and is widely recognized for a long time. One of the problems, in the last five years, has been the influx of "fake" ikat and even ikat textiles from outside East Sumba, which increasingly pushes the original ikat on the island of Sumba. There have been many "imitation" ikat weavings that use the original Sumba motif from the island of Java, forexample; Jepara, Pekalongan, Klaten, and other weaving clusters on the island of Java. This fact has implications for issues of performance, competitiveness, and sustainability of the ikat industry in East Sumba Regency which greatly impacts on the sources of employment and livelihoods of the local community. Therefore, this research will analyze the legal protection of the ikat-pahikung woven fabric motif in East Sumba Regency. This research is conducted by using field research (Empirical Research), which is to go directly to the field to conduct research using the Legal Sociology Approach, which is to examine and understand social phenomena in society to see the existing legal facts.

Keywords: Legal Protection; Law; Motive; Weaving Ikat
\end{abstract}

\section{Introduction}

The existence of a indigenous people in a country is recognized and protected by law through the constitution of Article 18B paragraph (2) of the 1945 Constitution. (Salam et al., 2016) one of the recognitions is the existence of ikat weaving sumba community. (Salam et al., 2016)lkat weaving has been a source of work, an important livelihood for families, and is widely known for a long time on Sumba Island. The existence of this weaving becomes the legal source of the existence of a society. (Safrin Salam, Nurwita Ismail, Faharudin, Nuragifah, Erni Dwita Lalubi, Shinta Nurhidayati Salam, Rosnida, 2020) (Safrin Salam, Nurwita Ismail, Faharudin, Nuragifah, Erni Dwita Silambi, Shinta Nurhidayati Salam, Rosnida, 2020) Ikat-pahikung weaving is a work of art that has a high value (socio-economic), targeted by the collectors of the world with a high price and has a good economic impact on the weavers who make it. However, behind the economic benefits enjoyed by traders, there are also some problems that occur such as production and marketing circulation does not run smoothly, the marketing chain is too long, market information is not available, and limited innovation and technology to strengthen the competitiveness and sustainability of ikat-pahikung weaving becomes complexity in the development of ikat weaving in East Sumba Regency. However, the fundamental problem today is that inthe last five years the entry of"imitation"ikat weaving (using the original motif of East Sumba) even ikat woven textiles from outside East Sumba are increasingly urgent for weavers of ikat-pahikung. There have been many found 'imitation'ikat weaving from the island of Java, for example; Jepara, Pekalongan, Klaten, and other weaving clusters of Java Island. This has implications on the issue of performance, competitiveness, and sustainability of the ikat weaving industry in East Sumba Regency.

The people of East Sumba have long made, worn and traded ikat woven fabrics known as East Sumba woven fabrics which in the local language are called Hinggi (men's custom dress in the shape of four rectangles) and Lawu or sarongs (Traditional clothing for women), while scarves can be worn by men and women who are stretched on the shoulders and headbands for men. Weaving activities are carried out manually and traditionally and are women's activities. Named ikat weaving because before being colored, the thread to be woven is tied with raffia rope or kalita on certain parts, then dipped in a natural dye liquid (blue or red). The part that is tied after 
opening remains white, while the untied partbecomes colored according to the color of the liquid (natural coloring). When woven the threads will form a pattern of ornamental variety with a certain color.

Sumba ikat-pahikung weaving has a variety of patterns and motifs (pictured) of ikat-pahikung woven fabric that a person uses shows his social status in society. Ikat-pahikung woven fabric is a fixture in traditional ceremonies (marriage, death), religion and art. Sumba ikat-pahikung weaving contains a symbolic meaning that is closely related to the conception of human life on earth and the hereafter. In the original belief of the People of Sumba(Marapu),the pattern is not just an image, but also emits the powerful power of the depicted. Therefore, certain woven fabrics of their use are adapted to the situation and place of use.

But the problem faced by weavers weaving ikat-pahikung today is the entry of artificial ikat weaving where the weavers feel aggrieved by the presence of artificial ikat weaving from outside Sumba Island. This is detrimental to the weavers because the "imitation" ikat weaving has used the original motifs of the East Sumba people where the motif has a traditional meaning. Therefore, it is necessary to strengthen the law in the protection of ikat weaving motifs in East Sumba Regency.

\section{Methodology}

Research methods have a specific purpose to obtain data using scientific means. (Darmadi, 2013) This type of research method in legal research uses Socio Legal methods. This research is a Legal Sociology Approach that examines and understands social symptoms in the community that cause losses to events / cases of East Sumba ikat weaving motifs that are imitated / taken. In this approach is done by observing directlyin order to find legal facts and know how legal protection of the motif of fabric-woven ikat pahikung in East Sumba Regency.

\section{Results and Discussion}

In traditional society wisdom becomes the identity of the existence of society one of which is woven fabric. (Greetings, 2017) (Salam, 2017)Motifis a work of art in the form of patterns to beautify a fine art, in this case the intended motif is a woven motif ikat-pahikung. According to Palulu P. Ndima in his book entitled "Cultural Studies of East Sumba lkat Woven Fabric" that weaving activities are carried out manually and traditionally and are women's activities. (Takandjandji, n.d.) Named ikat-pahikung weaving because before being colored, the thread to be woven is tied with raffia rope or kalita on certain parts, then dipped in a natural dye liquid (blue or red). Further explained by A. Langgar that ntt woven fabric where the tied part after opening remains white, while the untied part becomes colored according to the color of the liquid. When woven the threads will form a pattern of ornamental variety with a certain color. (Takandjandji, n.d.) The patterns and motifs of woven fabrics used by a person indicate their social status in society.

Ikat-pahikung woven fabric is a fixture in traditional ceremonies (marriage, death), religion and art until now Sumba ikat woven fabric as a cultural heritage still survives and develops cultural and economic value that is targeted by world collectors at high prices to be marketed both locally, nationally and internationally.

The protection of the law is an act or attempt to protect society from arbitrary acts by rulers that are not in accordance with the rule of law, to realize order and tranquility, thus enabling man to enjoy his dignity as a human being. (Setiono, 2004) While Satjipto Raharjo stated that the protection of the law is to provide protection to human rights (human rights) harmed by others and that protection is given to the community in order to enjoy all the rights granted by law. (Raharjo, 2000) Because the nature and purpose of the law according to him is to provide protection (protection) to the community, which must be realized in the form of legal certainty. Legal protection is an act for those that are preventive and repressive. (Hadjon, 1987)

Legal protection is a rule that regulates the rights of the people in this case citizens, in order to be protected from interference and threats. Valid guarantees as guidelines are used as guarantees to guarantee basic freedoms. Legal protection in the form of written regulations is used as protection to protecthuman rights. This legal pro tection becomes the essence of the existence of the law and the implementation of the purpose of the law that provides legal certainty, justice and legal expediency. (Greetings, 2020)(Salam, 2020)

Protection of ikat-pahikung weaving as a form of state / government presence and the entire community for the sustainability of ikat-pahikung weaving as the wealth of the people of East Sumba. One way of legal protection that can be done is by filing a geographical indigation document of ikat-pahikung weaving that is compiled as evidence of ikat-pahikung weaving is the wealth of the people of East Sumba. A geographical indication is a sign 
indicating the area of origin of an item and/or product that due to geographical environmental factors including naturalfactors, humanfactors, or a combination of the two factors confers a particular reputation, quality, and characteristics on the goods and/or products produced. This means that with the geographical indication document it will provide a clear policy direction in organizing resources in supporting the process of transformation of both human resources, natural resources and social value / capital resources of the community so that the weaving of the belts become an integrated economic force with other aspects, such as tourism, edu cation and the environment for sustainability of ikat-pahikung weaving; and a clear direction in provides / encourages the protection of ikatpahikung weaving.

Therefore, with geographical indications, legal protection for weavers / craftsmen of ikat - pahikung woven fabrics can be realized so that anyone who uses the motif of the East Sumba area will be given legal sanctions and east Sumba weavers will also not get losses.

\section{Conclusion}

Legal protection of the motif of ikat-pahikung woven fabric in East Sumba Regency is very important because it is a form of state protection against weavers (communities). With the establishment of Geographical Indication as a form of state / government presence for weavers or people of East Sumba for the sustainability of the woven motif of ikat-pahikung as the original wealth of the people of East Sumba. So that the state through the East Sumba regional government mustincrease the empowermentand protection of ikat-pahikung weaving in the strategic policy of the East Sumba Regency government, as well as formulate the synchronization of programs between the East Sumba Regency government and community elements in an effort to develop the direction of empowermentpolicy and protection of ikat-pahikung weaving. So it is thus true that the state is presentin providing legal protection over pahikung ikatweaving in East Sumba Regency, East Nusa Tenggara.

\section{References}

Darmadi, H. (2013). Metode Penelitian Pendidikan dan Sosial. Bandung: Alfabeta Bandung.

Hadjon, P. M. (1987). Perlindungan Hukum Bagi Rakyatindonesia. Surabaya: PT. Bina IImu.

Raharjo, S. (2000). IImu Hukum. Bandung: PT. Citra Aditya Bakti.

Safrin Salam, Nurwita Ismail, Faharudin, Nuragifah, Erni Dwita Silambi, Shinta Nurhidayati Salam, Rosnida, S. (2020). Perkembangan Filsafat Hukum Kontemporer. Yogyakarta: Zifatama Jawara. Retrieved from https://books.google.co.id/books?hl=id\&lr=\&id=Rf7_DwAAQBAJ\&oi=fnd\&pg=PA1\&dq=filsafat+hukum+kont emporer\&ots=dyKjINGBfl\&sig=fzoQVHDUZ4FP8vnedpkBdKUDcq4\&redir_esc=y\#v=onepage\&q=filsafat hukum kontemporer\&f=false

Salam, S. (2017). Analysis of Cooperation Agreements and Comparison Patterns of Out-of-Court Dispute Resolution. Jurnal Hukum Volkgeist, 2(1), 71-81.

Salam, S. (2020). Rekonstruksi Paradigma Filsafat IImu : Studi Kritis Terhadap IImu Hukum Sebagaillmu. Ekspose: Jurnal Penelitian Hukum Dan Pendidikan, 18(2), 885-896. https://doi.org/10.30863/ekspose.v18i2.511

Salam, S., Hukum, F., Muhammadiyah, U., Adat, D. H., Adat, M. H., \& Adat, H. (2016). Perlindungan Hukum Masyarakat Hukum Adat. Jurnal Hukum Novelty, 7(2), 73-88.

Setiono. (2004). Rule of Law (Supremasi Hukum). Surakarta: Magister IImu Hukum Pasca Sarjana Universitas Sebelas maret.

Takandjandji, M. D. M. (n.d.). Analisis Usaha TenunlkatBerbasis Pewarna Alam di Kabupaten Sumbatimur : kasus di Kecamatan Kambera dan Umalulu Analysis of Han. 